\title{
Moving to the sea: a challenge for an inshore species, the slender-billed gull
}

\author{
Albert Cama ${ }^{1,2,5, *}$, Rosa Abellana ${ }^{3}$, Isadora Christel ${ }^{1,2}{ }^{,}$Xavier Ferrer $^{1}$, \\ David R. Vieites ${ }^{2,4}$ \\ ${ }^{1}$ Institut de Recerca de la Biodiversitat i Departament de Biologia Animal, Facultat de Biologia, \\ Universitat de Barcelona, 08028 Barcelona, Spain \\ ${ }^{2}$ Museo Nacional de Ciencias Naturales (MNCN), Consejo Superior de Investigaciones Científicas (CSIC), 28006 Madrid, Spain \\ ${ }^{3}$ Departament de Salut Pública, Facultat de Medicina, Universitat de Barcelona, 08036 Barcelona, Spain \\ ${ }^{4}$ REFER Biodiversity Chair, University of Porto, CIBIO, Campus Agrário de Vairão, R. Padre Armando Quintas, 4485-661 Vairão, \\ Portugal \\ ${ }^{5}$ Present address: SEO/BirdLife. C/Murcia 2-8, Local 13, 08026 Barcelona, Spain
}

\begin{abstract}
The slender-billed gull Chroicocephalus genei is a typical saltpan and brackish lagoon inshore forager. In 2005, there were two breeding colonies in the Ebro Delta (western Mediterranean): one south of the delta on a large saltpan, and the other one in the north, where typical foraging habitats are scarce. Aerial surveys showed that gulls foraged at sea throughout the study period, but were mainly restricted to the northern part of the delta from June to August. We compared 6 different approaches to model the gulls' distribution at sea: Poisson generalized linear model (GLM), zero inflated Poisson GLM, spatial Poisson generalized linear mixed model (GLMM), non-spatial Poisson GLMM, negative binomial GLM and zero inflated negative binomial GLM. The best approach, simple negative binomial GLM, suggested that the gulls' distribution was mainly influenced by the proximity to the colony, tern density and water temperature. The water temperature was indicative of river runoff, which resulted in an anchovy population explosion, explaining the gulls' extensive foraging at sea in summer. Slender-billed gulls are capable of changing their foraging strategy to exploit resources at sea when occupying an area with limited terrestrial but abundant marine resources. Population growth in the western Mediterranean may lead to the occupancy of non-typical habitats elsewhere. Because slenderbilled gulls are rare and have an unfavorable conservation status, conservation policies affecting this species should be extended to the sea.
\end{abstract}

KEY WORDS: Chroicocephalus genei - Distribution modeling · Ebro Delta $\cdot$ Mediterranean Sea · Anchovy · Generalized linear model (GLM) · Generalized linear mixed model (GLMM)

\section{INTRODUCTION}

To exploit marine resources, seabirds have evolved physiological and morphological adaptations, as well as a wide variety of foraging strategies (see review in Shealer 2002). Marine birds show a gradient of dietary specialization that spans from opportunistic species with a wide dietary spectrum (Furness \& Camphuysen 1997, Chapman et al. 2004), to highly specialized species that only feed on a particular resource (Furness \& Camphuysen 1997, Votier et al. 2004a). Changes in food resources can severely affect population dynamics of these specialized species, because it is difficult for them to adapt to alter- 
native food resources (Croxall et al. 1999, Wanless et al. 2005). Since breeding seabirds are central place foragers (Orians \& Pearson 1979), searching for alternative feeding areas results in an increase in foraging ranges (Oro et al. 1996). However, increased foraging costs affect breeding success (Kitaysky et al. 2000, Navarro \& González-Solís 2007). In extreme situations, e.g. cape gannets (Morus capensis) in the Benguela upwelling zone, increases in the distance to food resources likely cause the birds to change colony locations to reduce foraging ranges and energetic costs (Gremillet et al. 2008). This extra cost probably has a greater effect on species that establish their colonies close to foraging areas (Oro 1996, Villablanca et al. 2007). Overall, when the availability of a feeding resource diminishes, seabirds must either increase their foraging range and their energetic costs (Suryan et al. 2000, Navarro \& GonzálezSolís 2007), or change their foraging strategy to exploit alternative food resources close to the colony (Montevecchi et al. 2009, Votier et al. 2004b).

We investigated changes in the foraging range of a typically inshore gull species, the slender-billed gull Chroicocephalus genei, in the Ebro Delta, western Mediterranean Sea. This medium-sized gull has a scattered coastal distribution from Senegal to NW India through the Mediterranean, Black and Red seas, the Persian Gulf and some inland waters of SW Asia (Burger \& Gochfeld 1996). This gull forages mainly in saltpans and brackish lagoons, but also in mouths of channels and lagoons, intertidal flats and seashores (Dementev \& Gladkov 1969, Fasola et al. 1989, Cramp \& Simmons 2004). The slender-billed gull has been reported to be scarce in offshore waters of the Ebro Delta (Oro \& Ruiz 1997, Arcos 2001, Martínez-Vilalta et al. 2004, Oro et al. 2004). Only Meinertzhagen (1954) describes marine occurrence of $C$. genei from offshore waters near the Arabian peninsula, outside the breeding season. Other authors, however, consider this as anecdotal evidence (Dementev \& Gladkov 1969, Fasola et al. 1989, Cramp \& Simmons 2004, Martínez-Vilalta et al. 2004).

The slender-billed gull has 3 breeding colonies in the Ebro Delta (Fig. 1). Two (La Banya and La Tancada) are located on the southern Ebro Delta saltpans (the first is active and the second is abandoned). The third (El Fangar) was colonized in 2001 (Oro 2002) and is located to the north, on a sandy peninsula lacking brackish marshes and saltpans. In the south, there are $8.4 \mathrm{~km}^{2}$ of saltpans (see Fig. 1a), $4.3 \mathrm{~km}^{2}$ of brackish lagoons and $64 \mathrm{~km}$ of shoreline, but in the north, there is a brackish lagoon of only $1.0 \mathrm{~km}^{2}$, and
$25 \mathrm{~km}$ of shoreline without saltpans. These differences in inshore foraging habitats may drive differences in the use of alternative foraging areas, such as the sea.

In this study we aim to: (1) report the use of marine habitats by the slender-billed gull in the study area, and describe its distribution pattern at sea during the breeding season ${ }_{i}(2)$ compare the marine densities of this species in areas with different availabilities of typical inshore habitats; (3) determine which variables best explain marine densities using several modeling approaches; and (4) test different modeling methods for this purpose and discuss their use for distribution modeling in marine organisms.

\section{MATERIALS AND METHODS}

\section{Study area}

We studied the marine area around the Ebro Delta in the western Mediterranean (Fig. 1) which measured $1435 \mathrm{~km}^{2}$. The area is very productive because of the influence of the Liguro-Provençal-Catalán front and runoff from the Ebro River. Its oceanographic characteristics are described in Salat et al. (2002) and Arin et al. (2005). Monthly aerial surveys were conducted in 2005 during the breeding season of the slender-billed gull, from April to August.

In 2005, the slender-billed gull bred in only 2 colonies, La Banya and El Fangar, which are located at the southern and northern extremes of the Ebro Delta, respectively (Fig. 1a). That year, 309 slenderbilled gull pairs inhabited La Banya and 109 inhabited El Fangar (Ebro Delta Natural Park and IMEDEA pers. comm. with D. Oro, A. Bertolero and A. Cureó). For data analyses, the study area was divided into 3 sectors (Fig. 1a). These included (1) the northern $\left(472 \mathrm{~km}^{2}\right)$ and (2) southern $\left(624 \mathrm{~km}^{2}\right)$ Ebro Delta sea waters, and (3) part of the Castellón coast, referred hereafter as Castellón $\left(416 \mathrm{~km}^{2}\right)$. The northern area spans from the northern edge of the Delta to the river mouth and up to $23 \mathrm{~km}$ offshore, including the El Fangar colony. This area is crossed by the main part of the river plume, which is usually directed northwards during summer (Fig. 1b) (Mestres et al. 2003, Mösso et al. 2003). The southern part of the Ebro Delta (off La Banya) includes the Delta coast from the river mouth to its southern limit including the main slender-billed gull colony, La Banya. In summer, this area is influenced by the river plume to a lesser extent (Mestres et al. 2003, Mösso et al. 2003), so oceanographic conditions contrast to the northern 
Ebro Delta (e.g. Fig. 1b). Further south, Castellón is in the southern part of the study area which is outside the Ebro Delta.

\section{Aircraft surveys}

To assess potential changes in the gull's distribution at sea, we performed 5 aerial surveys on 21 April, 20 May, 15 June, 29 July and 12 August 2005,
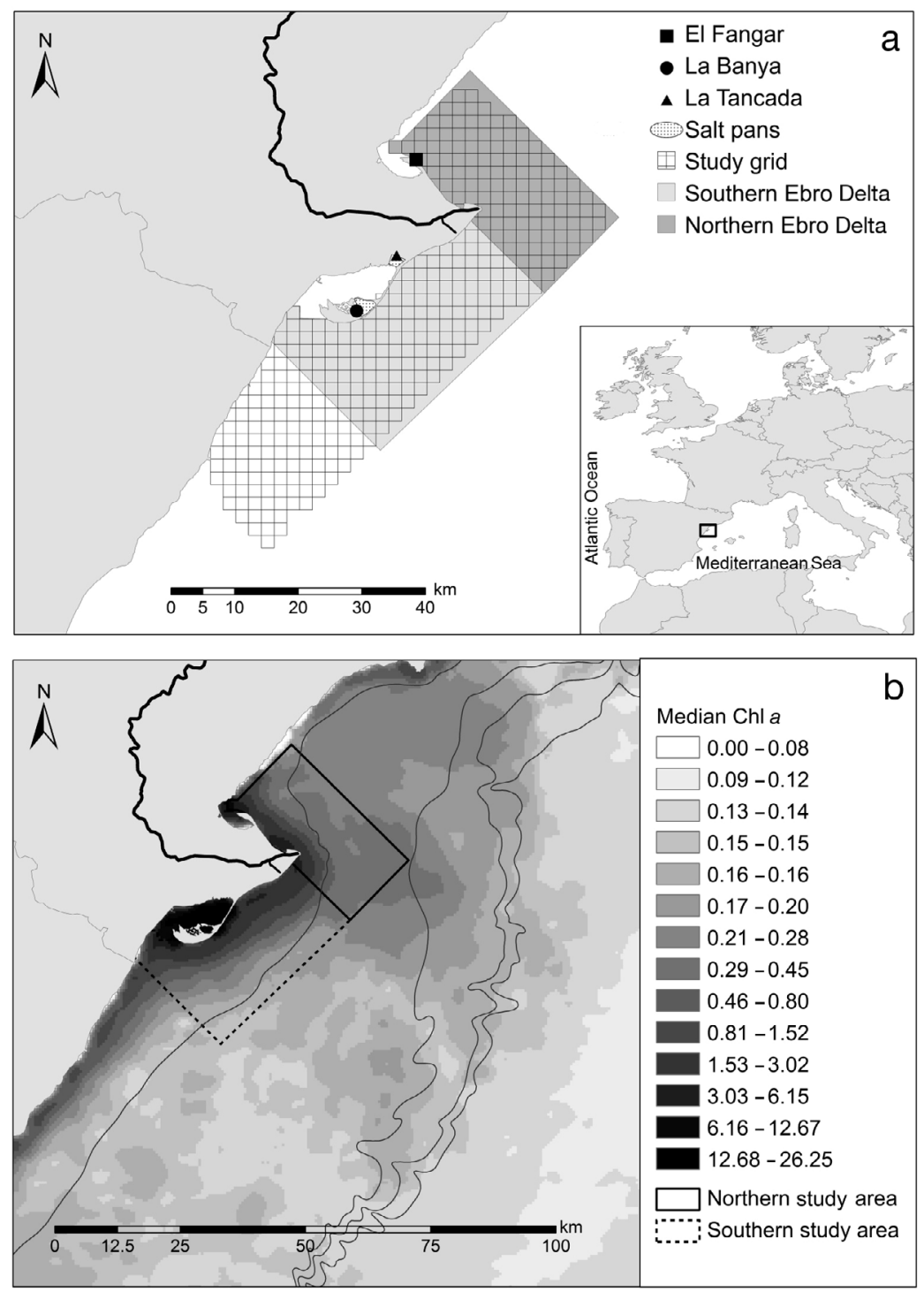

Fig. 1. Study area. (a) Location of the Ebro Delta and the 3 surveyed areas in the western Mediterranean. The zone within the grid not highlighted to the south of the southern Ebro Delta is the Castellón area. The 3 slender-billed gull breeding colonies and the surface of saltpans in the Ebro Delta are shown (La Tancada was not occupied in 2005 when the surveys were conducted). (b) July and August 2005 median chlorophyll a concentrations $\left(\mathrm{mg} \mathrm{m}^{-3}\right)$. The chl a values were scaled using geometric intervals. Isobaths corresponding to 50 , 100,200 and $400 \mathrm{~m}$ are shown overlapping with the breeding season of slenderbilled gulls in the area. We used the standard seabird aerial survey methodology described elsewhere (Noer et al. 2000, Christensen et al. 2001) with minor adaptations (see Cama et al. 2012). This census method was chosen because it allows the coverage of large areas as simultaneously as possible, with minimum disruption to the patterns of abundance and distribution of birds (Fox et al. 2006). This method is suitable for seabird censuses (Fischer \& Larned 2004,

Fox et al. 2006) and has previously been applied successfully to the study area (Cama et al. 2012).

The surveys were conducted from a Partenavia P-68 twin-engine aircraft. The aircraft followed 45 predefined transect lines ranging from 13 to $23 \mathrm{~km}$ long and separated by a constant distance of $2 \mathrm{~km}$. Position data were automatically recorded to a GPS unit every 5 s. The aircraft flight altitude was $300 \mathrm{ft}$ (ca. $100 \mathrm{~m}$ ) and the flight speed was 100 knots (ca. $185 \mathrm{~km} \mathrm{~h}^{-1}$ ) with respect to air speed. All censuses were performed under optimal visibility conditions and with wind speeds $<5 \mathrm{~m} \mathrm{~s}^{-1}$. Each census lasted ca. $6 \mathrm{~h}$.

Censuses were carried out by 2 observers using Steiner Commander V $7 \times 50$ binoculars. During these censuses, all observed bird flocks in a $2 \mathrm{~km}$ band $(1 \mathrm{~km}$ each side of the aircraft) were registered. An inclinometer was used to define the limit of the $1 \mathrm{~km}$ band. At the established flight height, the limit of $1 \mathrm{~km}$ is found ca. $6^{\circ}$ under the horizontal axis. The area spanning 59 m directly under the aircraft was not visible (Noer et al. 2000, Christensen et al. 2001).

For all bird groups, information about species, number of individuals and time of the observation was recorded. In summer, slender-billed gulls can be reliably identified from great distances, since the combination of wing and head patterns is highly distinctive from other gull species (Blomdahl et al. 2002, Olsen \& Larsson 2003). However, we were unable to precisely identify some distant individuals to species level. 
Fishing boats were also recorded, specifying the type of boat and its fishing activity. Fishing boats can be an important food resource for seabirds, as they can provide food in the form of fish discards, which are easy to capture, abundant and predictable in time and space (Tasker et al. 2000, Arcos et al. 2008, Cama et al. 2012), but the number of fishing boats (4 in July and 5 in August) was too low to include as a variable in the models.

To avoid inconsistent detection and identification rates, data were not recorded when observation was hindered by technical problems, glare or other poor light conditions. The incidence of technical or visual problems was registered and considered in data processing. Observations were linked with GPS information with a Turbo Pascal application (I. K. Petersen pers. comm.).

\section{Comparing inter-colonial marine densities}

We used the program ArcGIS version 9.2 to create $2 \times 2 \mathrm{~km}$ grids, and to summarize survey information in the 378 resulting grid cells. The grids were then divided among 3 areas, resulting in 118 cells located at the northern delta, 156 at the southern delta and 104 in the Castellón area. The grid cells were used as geographical units in the analyses. To compare densities at sea, we generated a simple Poisson model (McCulloch \& Searle 2001) of the density of gulls in each month, with sector (north or south) as a variable. The log-likelihood of this model was compared with that of the model without any variables using the likelihood ratio test (LRT). The Castellón area was not included in these analyses.

\section{Modeling the gulls' marine distribution: data processing}

To model the distribution of the species at sea, we defined 10 variables for each region and for each census that had a large enough sample size. Those included biological variables, such as the number of terns, the number of other gull species and the chlorophyll a (chl a) concentration and its gradient, physical variables, such as the sea surface temperature (SST) and its gradient, the distances to the closer breeding colony and to the river mouth, and a temporal variable (the month of the survey). For the models, we used the surface covered per grid during aerial surveys as an offset.
SST and chl $a$ are used to indicate the primary production of marine environments (Morel \& Berthon 1989, Bricaud et al. 2002) and are associated with seabird distribution (e.g. Hyrenbach et al. 2007, Louzao et al. 2006). These variables were measured by the Aqua (EOS PM) Satellite of the MODIS NASA project (http://modis.gsfc.nasa.gov/), using the Catalán chl $a$ and SST map server Thalassa (www.opengis. uab.es/WMS/thalassa/index.htm). This server provides $1 \times 1 \mathrm{~km}$ data for the GIS Miramon program (Pons 2011) that can be easily exported to ArcGIS 9.2. Punctual data were assigned to the corresponding grid cell for the analyses. Data taken during the $8 \mathrm{~d}$ before the flights were used to calculate median chl a and SST in each grid cell. We also calculated the spatial gradient of these variables in the following way: [(max. value - min. value) $\times 100] /$ max. value (Louzao et al. 2006). As described by Louzao et al. (2006), only the grids with $>1$ valid chl a value (i.e. between 0.05 and $50 \mathrm{mg} \mathrm{m}^{-3}$ ) were taken into account for the analyses. Median daily chl a was calculated for each $1 \times$ $1 \mathrm{~km}$ grid cell in July and August (Fig. 1b). Data points were interpolated to generate a continuous map using the kriging function in ArcGIS 9.2.

We used the river mouth as a geographical landmark because it creates local differences in environmental and water productivity (Salat et al. 2002, Arin et al. 2005). The distance to the breeding colony was also included. In preliminary analyses using Spearman's rank correlations, other geographical variables (e.g. water depth and its gradient, and the distance to the coast) were rejected because of high correlations with the included variables.

Densities of other bird species were included as variables in the model to assess interspecific interactions. The species were grouped into 2 categories: terns (mainly common and Sandwich terns) and other gull species (mainly yellow-legged gulls Larus michahellis and Audouin's gulls L. audouinii). We neglected other seabird species (shearwaters, storm petrels, skuas, etc.) because their densities were very low and probably did not affect the distribution of slender-billed gulls at sea.

\section{Modeling the gulls' marine distribution: data analyses}

For a general scheme of the modeling approach see Fig. 2. The variables were incorporated into a multivariate Poisson generalized linear model (GLM), also considering the possible interactions with survey month. Univariate models were conducted using all 


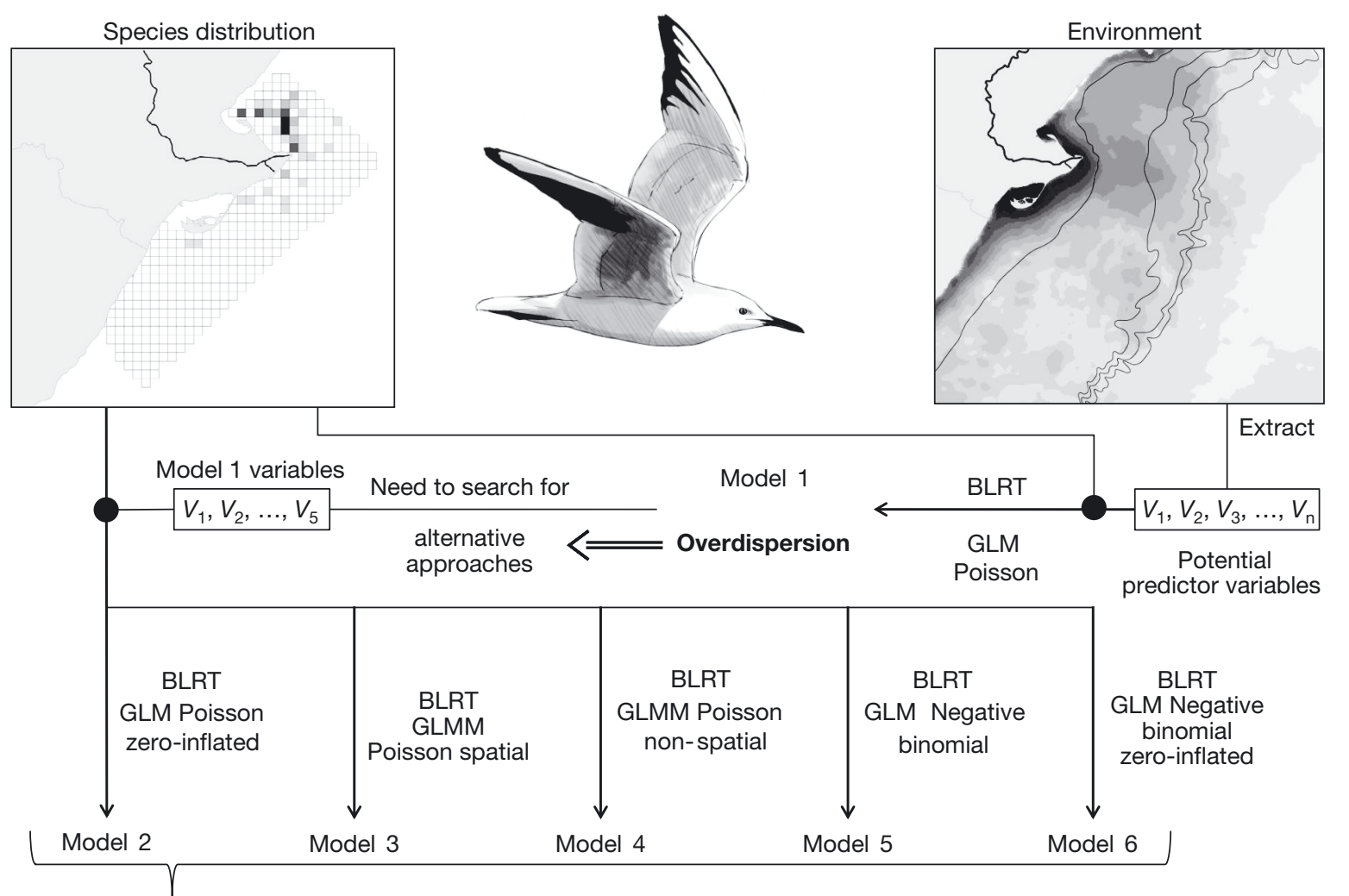

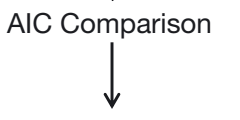

Final Model

Fig. 2. Chroicocephalus genei. Gull distribution model construction and selection procedure workflow. Based on the predictive variables and the species distribution we performed a Poisson GLM (Generalized Linear Model). The variable selection was conducted through a backward process using the Likelihood Ratio Test (BLRT). This model showed overdispersion and the search for alternative distributions was needed. The alternative models built with the variables selected in the Poisson model were compared with the Akaike Information Criterion (AIC)

the variables, and only those correlated with the density of slender-billed gulls were included in the multivariate model. A backward process, based on likelihood ratio tests (LRT), was used to eliminate non-significant variables in the multivariate model. The first modeling approach was GLM following the Poisson distribution, which is described by the following function:

$$
\log \left[E\left(Y_{i}\right)\right]=\beta_{0}+\beta_{1} x_{1 i}+\ldots+\beta_{k} x_{k i}+\log \left(\operatorname{cov}_{i}\right)
$$

where $\left[E\left(Y_{i}\right)\right]$ is the expected number of slenderbilled gulls in the ith geographical unit, $i=1 \ldots \mathrm{N}, \beta_{0}$, $\ldots \beta_{\mathrm{k}}$ are the coefficients of the model, $x_{1 i} \ldots x_{k i}$ are the variables evaluated in the $i$ th geographical unit (i.e. the units the grid cells shown in Fig. 1a) and $\operatorname{cov}_{i}$ is the coverage effort value in the ith geographical unit and the offset of the regression.

We used 3 different approaches to adjust the overdispersion of the Poisson model (the best model fit is found when overdispersion $=1$ ) .

(1) We analyzed whether the overdispersion was due to a zero excess in the data by using a zero inflated regression (Lambert 1992). This regression controls the extra proportion of zeros with the parameter $p_{i} \in[0,1]$, and the expectation of the number of slender-billed gulls in the ith geographical unit, is $E\left(Y_{i}\right)=\mu_{i}\left(1-p_{i}\right)$ and its variance is $\operatorname{Var}\left(Y_{i}\right)=\mu_{i}\left(1-p_{i}\right) \times\left(1+\mu_{i} p_{i}\right)$.

(2) We used the negative binomial model (Lawless 1987), because it allows the variance of the distribution to vary from the expected variance by introducing an additional parameter in the variance $(k)$ :

$$
\operatorname{Var}\left(Y_{i}\right)=E\left(Y_{i}\right)+k\left[E\left(Y_{i}\right)\right]^{2}
$$

where $k$ is the additional parameter of the negative binomial.

A zero-inflated model with the following expression was also conducted with the negative binomial distribution. This distribution differs from the Poisson zero inflated model because of the variance, which is described by the following expression $\operatorname{Var}\left(Y_{i}\right)=$ $\mu_{i}\left(1-p_{i}\right)\left[1+\mu_{i}\left(p_{i}+k\right)\right]$.

(3) We used a Poisson regression with regional random effects. Two types of random effects were considered; the first contained spatially structured effects. The existence of this spatial correlation means that the bird density of geographically close 
regions tends to be similar. To take into account the spatial autocorrelation, we modeled the neighboring relationships, considering the regions with common borders to be neighbors. This spatial structure was specified by using a conditional spatial autoregressive (CAR) model (Besag 1974) and the resulting model is described by the following expression:

$$
\log \left[E\left(Y_{i}\right)\right]=\beta_{0}+\beta_{1} X_{1 i}+\ldots+\beta_{k} X_{k i}+\log \left(\operatorname{Cov}_{i}\right)+S_{i}
$$

where $s_{1} \ldots s_{\mathrm{N}}$ follows a normal multivariate (NMV) distribution with a mean equal to ' 0 ' and variance equal to $\mathrm{SD}_{\mathrm{CAR}}{ }^{2} \times \mathrm{Q}^{-1}\left(0, \mathrm{SD}_{\mathrm{CAR}}{ }^{2} \times Q^{-1}\right), s_{i}$ is the spatial dependence factor for the $i$ th geographical unit, $\mathrm{SD}_{\mathrm{CAR}}{ }^{2}$ is the variance of the spatial aggregation (CAR) random effects and $Q^{-1}$ is a matrix that defines

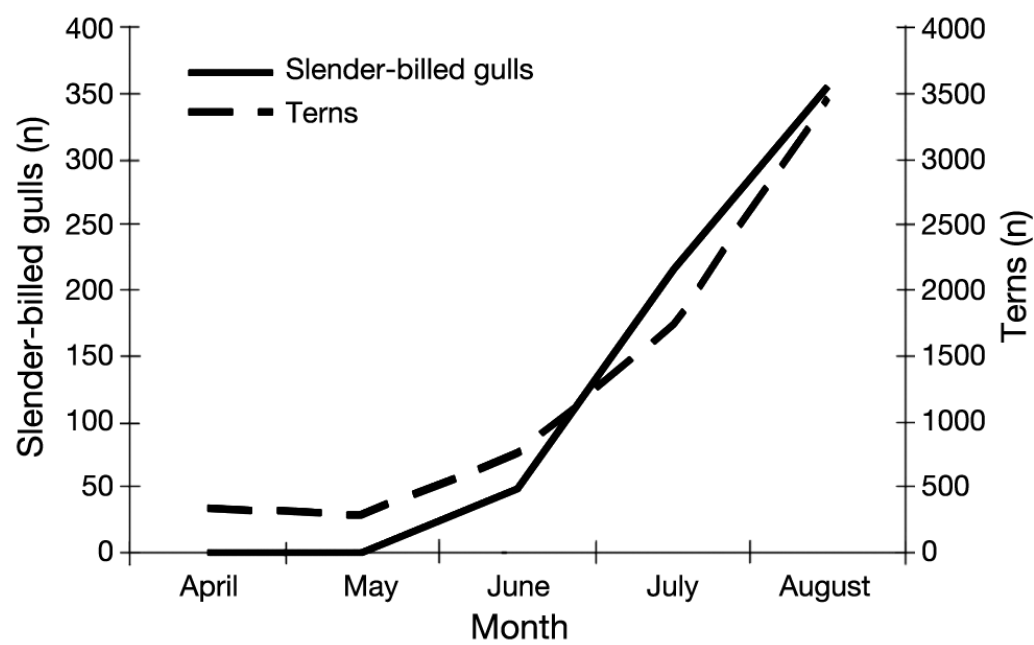

Fig. 3. Chroicocephalus genei and Sterna spp. Total recorded slender-billed gulls and terns in the northern Ebro Delta coast during the 2005 breeding season (from April to August)

Table 1. Chroicocephalus genei. Comparison of inter-colonial offshore densities (Poisson generalized linear models). Number of slender-billed gulls (SBG) and average densities (SBG km${ }^{-2}$ ) recorded off northern and southern Ebro Delta coasts and their 95\% CI. The results for the Castellón coast are also shown. For the northern and southern areas, likelihood ratio tests (LRT) were used to compare the null SBG density model with the univariate model with colony as the variable for both July and August

\begin{tabular}{|c|c|c|c|c|}
\hline Month & Area & SBG nr. & $\begin{array}{c}\text { Average SBG } \\
\text { density }(95 \% \text { CI) }\end{array}$ & $\begin{array}{l}\text { LRT } \\
\text { (p) }\end{array}$ \\
\hline June & $\begin{array}{l}\text { North } \\
\text { South } \\
\text { Castellón }\end{array}$ & $\begin{array}{r}48 \\
27 \\
0\end{array}$ & $\begin{array}{l}0.12(0.09,0.15) \\
0.04(0.03,0.06) \\
0.00(0.00,0.01)\end{array}$ & $15.24(<0.01)$ \\
\hline July & $\begin{array}{l}\text { North } \\
\text { South } \\
\text { Castellón }\end{array}$ & $\begin{array}{r}216 \\
62 \\
0\end{array}$ & $\begin{array}{l}0.62(0.54,0.71) \\
0.14(0.11,0.18) \\
0.00(0.00,0.01)\end{array}$ & $131.54(<0.01)$ \\
\hline August & $\begin{array}{l}\text { North } \\
\text { South } \\
\text { Off Castellón }\end{array}$ & $\begin{array}{r}354 \\
13 \\
0\end{array}$ & $\begin{array}{l}0.96(0.86,1.06) \\
0.03(0.02,0.05) \\
0.00(0.00,0.01)\end{array}$ & $458.58(<0.01)$ \\
\hline
\end{tabular}

the neighborhood relations between the geographical units.

The second type of regional random effects was an tern. This approach is described as follows:

$$
\log \left(E\left[Y_{i}\right]\right)=\alpha_{0}+\beta_{1} x_{1 i}+\ldots+\beta_{k} x_{k i}+\log \left(\operatorname{Cov}_{i}\right)+b_{i}
$$

where $b_{i}$ is the heterogeneity factor for the ith geographical unit, $b_{1} \ldots b_{\mathrm{N}} \sim \operatorname{NMV}\left(0, \mathrm{SD}_{\mathrm{HET}}^{2} \times I_{\mathrm{N}}\right)$, $\mathrm{SD}_{\mathrm{HET}}{ }^{2}$ is the variance of heterogeneity (HET) random effects and $I_{\mathrm{N}}$ is the identity matrix.

The models were compared using the Akaike information criterion (AIC) (Akaike 1974). To test the final model fit, Pearson residuals (the raw value divided by the square root of the variance function) were calculated for each observation. Since Pearson residuals are approximately normally distributed, Pearson residuals exceeding an absolute value of 2 (95\% CI in normal distribution) may indicate a lack of fit. The functions Proc Genmod and Glimmix of the SAS program version 9.1 and MASS and epitools library of the $\mathrm{r}$ package version 2.9 were used to develop the models. The process for selecting the final model is summarized in Fig. 2.

\section{RESULTS}

\section{Survey results: comparing inter-colonial marine densities}

720 slender-billed gulls were recorded during the surveys: 0 in April and May, 75 in June, 278 in July and 367 in August (Fig. 3 \& Table 1). During April and May, slender-billed gulls were not detected at sea in any part of the study area. In June, the gulls were distributed mainly in the frontal delta area of the northern study area (Table 1). In July and August, the density of the gulls increased in the northern study area (Table 1 \& Fig. 4), while the abundance of the 

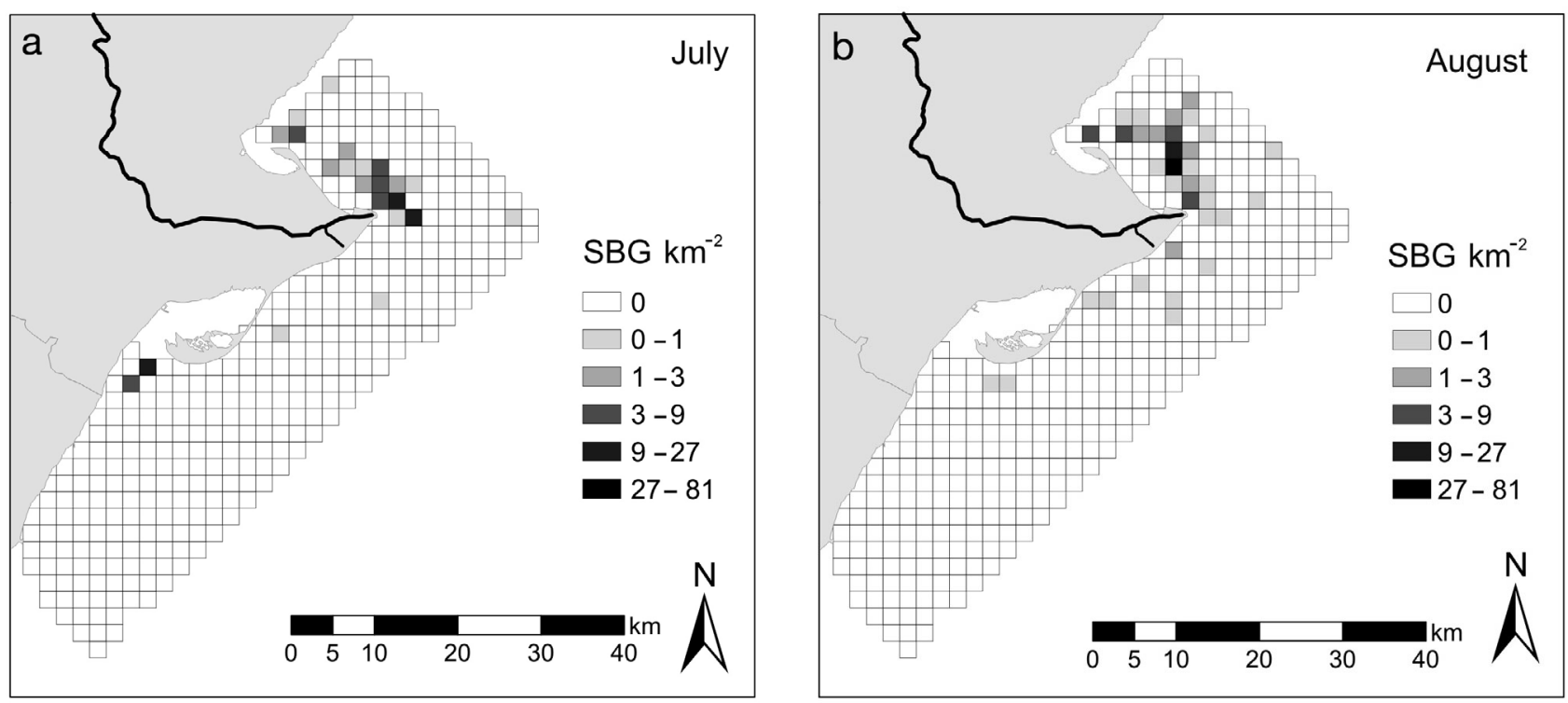

Fig. 4. Chroicocephalus genei. Observed slender-billed gull (SBG) densities during (a) July and (b) August 2005 aircraft surveys

gulls at sea in the southern Ebro Delta was minimal, despite larger numbers of breeding pairs in the colony. Slender-billed gulls were not detected off the northern Castellón coast.

\section{Modeling the gulls' marine distribution}

The number of slender-billed gulls was only high enough for distribution modeling on the northern Ebro Delta coast in July and August (Table 1); distribution modeling was not possible in the southern part of the study area, where the gulls were scarce. The variables that were used in the model were the distance to the colony and its interaction with month, distance to the river mouth, SST median and gradient and their interaction with month, and tern density. The first approach, the Poisson model, showed a high overdispersion value (2.30), so we explored alternative models with the same explanatory variables. The zero inflated Poisson model fit the data better than the regular Poisson model (AIC $=1285$ vs 1316, respectively). However, the negative binomial distribution reduced the value of AIC to 429.1. The zero inflated negative binomial model showed similar performance to the simple negative binomial model (AIC $=431.0$ ). The Poisson non-spatial and spatial models did not perform as well as the other models, with AIC values of 1453 and 1401, respectively. Finally, the negative bi- nomial distribution was selected as the most suitable for our data. This model explained $56 \%$ of the deviance and reduced the overdispersion to 0.99 . In the negative binomial model, only 8 of the 236 grids (118 in each survey) showed standardized Pearson residual values $>2$, suggesting a good model fit. The model comparison is summarized in Table 2.

Table 3. Chroicocephalus genei. Negative binomial model of slender-billed gull density, with coefficients for each variable and $95 \%$ CI. Negative binomial parameter $=5.16$,

$$
\mathrm{SE}=1.05
$$

\begin{tabular}{|lcccr|}
\hline Variable & Month & $\begin{array}{c}\text { Coeffi- } \\
\text { cient }\end{array}$ & \multicolumn{2}{c|}{$\begin{array}{c}\text { Coefficient } \\
95 \% \text { CI }\end{array}$} \\
\hline $\begin{array}{l}\text { Tern density } \\
\text { Distance }\end{array}$ & & 0.04 & 0.01 & 0.06 \\
$\begin{array}{l}\text { to the colony } \\
\text { SST median }\end{array}$ & July & 3.46 & -0.34 & -0.17 \\
& August & -3.15 & -8.09 & 1.92 \\
& & & & \\
\end{tabular}


In the negative binomial model (Table 3) the density of slender-billed gulls was negatively associated with distance to the colony. The SST median was positively correlated with gull density in July, but was not significantly correlated in August. The density of slender-billed gulls was positively associated with tern density in both months. The overall number of slender-billed gulls and the number of terns (see Fig. 3) was also positively correlated among surveys (Spearman $\rho=0.975$, $p=0.005$ ).

\section{DISCUSSION}

\section{Slender-billed gull marine presence}

The slender-billed gull, a species that mainly forages on saltpans and brackish lagoons inshore (Dementev \& Gladkov 1969, Fasola et al. 1989, Oro 2002) extensively uses open marine waters off the Ebro Delta. Although gull colonies are found in both the south and the north of the delta, the presence of gulls at sea is restricted to the northern part during July and August. The southern colony is located on a saltpan with abundant typical foraging habitat, so the gulls can access their common food resources inshore. The northern colony was established in 2001 and has persisted until now, though there are no saltpans, likely because the high availability of fish due to the particular oceanographic conditions in this area allowed foraging at sea.

The selected model (the negative binomial distribution) highlights that many slender-billed gulls were found near the colony of El Fangar (Fig. 4), although in late July and August, breeding activity — and its associated constraints - expired. High gull abundance at El Fangar Bay was probably due to the adequate habitat found there.

Our results suggest a positive correlation between the density of slender-billed gulls and median SST in July, but not in August, or with other oceanographic variables (SST gradient or chl a median and gradient). In July, the SST can be interpreted as a proxy for the presence of river runoff, since then the river runoff is warmer than the sea, suggesting that slender-billed gulls are attracted to the general area of the river plume, which enters the sea over a wide area.

Fishing boats were scarce when slender-billed gulls were observed out at sea. This suggests little utilization of discards by the gulls, and agrees with previous reports (Oro \& Ruiz 1997), but is in contrast with other seabird species in the area (Arcos 2001, Cama et al. 2012).
Slender-billed gulls forage preferentially with terns (mainly common terns Sterna hirundo). Kleptoparasitism by slender-billed gulls has been observed (Martínez-Vilalta et al. 2004), but it is not clear if this factor alone drives the marine presence of slenderbilled gulls. As a consequence, it is likely that both species feed on the same, or closely related, prey. The gulls can use tern flocks to locate the clupeiform (mainly anchovy Engraulis encrasicolus and sardine Sardina pilchardus) shoals on which terns forage (Hernández-Matías \& González-Solís 2004). Unlike sardines, anchovies spawn during the spring, and their eggs and larvae are most abundant in the study area during summer (Olivar et al. 2001, Palomera et al. 2007, Sabatés et al. 2007). In addition, anchovies can survive in habitats of variable salinity (Sabatés et al. 2007) such as our study area. The timing of this resource coincides with the observed increase in seabird numbers at sea and the last stages of the breeding season, when chick feeding needs are higher and fledglings start fishing on their own (Dementev \& Gladkov 1969, Cramp \& Simmons 2004). Feeding on anchovy schools by slender-billed gulls was also reported in a coastal lagoon system in the Black Sea (Dementev \& Gladkov 1969).

The significant differences between the northern and southern densities of slender-billed gulls at sea can be partially explained by inshore habitat differences. Unlike the southern colony, the northern colony is located in an area with a small amount of typical foraging habitat. As a consequence, food may be limited, and gulls may be forced to find alternative food resources. In summer, river runoff affects the northern part of the delta to a greater extent than the southern one (Mestres et al. 2003, Mösso et al. 2003). In addition, the southward Liguro-Provençal-Catalán current supplies the northern coast with nutrients by the penetration of slope water into the sea shelf when the shelf widens (Salat et al. 2002). This general oceanographic scenario results in a more coastal distribution of the anchovy off the northern delta (García \& Palomera 1996, Olivar et al. 2001). Further trophic and comparative inter-colonial tracking studies would help to clarify the relationships between gulls and their prey.

\section{Methodological considerations}

We compared several approaches to model the density distribution of slender-billed gulls at sea, to select the most suitable method to explore the influence of different variables on gull density. The 
negative binomial distribution was the most suitable one for our data, as suggested by AIC comparison between models. Modelling marine organisms faces the challenge of dealing with distributions with many absence areas (zero presence). Our comparative approach suggests that screening several methodological approaches is preferable to a single-method approach in order to properly model the distribution of marine organisms. It will be relevant to test the statistical modeling methods used in our study on other species, to assess whether negative binomial distributions perform consistently better.

\section{CONCLUSIONS}

This study exemplifies the use of different tools for modeling density distributions characterized by a high ratio of empty grids and a high deviance in density with outlier values. Many marine organisms are distributed in this patchy pattern, including many seabirds and their prey (Weimerskirch 2007, Fauchald 2009), billfishes (Ortiz \& Arocha 2004), or benthic macroinvertebrates (Gray 2005, Vincenzi et al. 2006).

The slender-billed gull forages extensively at sea, showing a heretofore unnoticed foraging plasticity that is similar to that in other gull species (Oro 1996, Stenhouse \& Montevecchi 1999, Hüppop \& Wurm 2000). However, sea foraging occurs only under very good foraging conditions at sea, which are provided by temporary resources. Slender-billed gulls were not detected in the study area in previous studies (Oro \& Ruiz 1997, Arcos 2001), suggesting that foraging behavior has recently diversified. This was likely influenced by the colonization of an area lacking favorable habitats inshore. It is unclear if this gull is able to perform the same behavior in other areas of the Mediterranean, although early reports stated that it is found sporadically at sea (Meinertzhagen 1954). The population growth of slenderbilled gulls detected in the western Mediterranean during the last 2 decades (Oro \& Tavecchia 2008) may be related to the previously unreported utilization of alternative foraging areas at sea. Further confirmation of this behavior in other areas is needed. The foraging of slenderbilled gull at sea is relevant for management decisions on the conservation of this species, which has an unfavorable conservation status in Europe: current policies focus on the management of inshore habitats and do not consider open waters or interactions with fish stocks. These factors will need to be taken into account in the future.
Acknowledgements. We are very grateful to X. Macià for work during the aircraft surveys. The help of I. K. Petersen was very valuable for survey planning, development and data processing and the help of M. Louzao and I. Serral for remote sensing information analyses. We are grateful to the Ebro Delta Natural Park team: D. Bigas, F. Vidal and A. Curcó, for the information and facilities provided. P. Isenmann, M. Fasola, L. Cadahía, I. Palomera, M. Alcaraz, J. Salat, T. Hernández, D. Oro and P. Arcos provided valuable help and comments. Many thanks to M. Rodríguez for the slender-billed gull drawing in Fig. 3. The Fundació Bosch i Gimpera has made possible the relationship between the research team and Capital Energy which supported this work with Projects no. 303052, 303289 and 303833. This work was partly supported by a Spanish Ministry of Science and Innovation grant (CGL2009-10198) to D.R.V. I.C. acknowledges the University of Barcelona for the APIF grant and A.C. the Generalitat de Catalunya for the financial support of a Doctoral fellowship of the FI programme (no. 2009FIC75).

\section{LITERATURE CITED}

Akaike H (1974) A new look at the statistical model identification. IEEE Trans Automat Contr 19:716-723

Arcos JM (2001) Foraging ecology of seabirds at sea: significance of commercial fisheries in the NW Mediterranean. Universitat de Barcelona, Barcelona. Accessed 12 May 2010. www.tesisenred.net/bitstream/handle/10803/775/ TOL38.pdf? sequence $=1$

Arcos JM, Louzao M, Oro D (2008) Fishery ecosystem impacts and management in the Mediterranean: seabirds point of view. In: Nielsen JL, Dodson JJ, Friedman K, Hamon TR, Musick J, Verspoor E (eds) Reconciling Fisheries with Conservation: Proc 4th World Fish Congr. American Fisheries Society, Bethesda, MD

Arin L, Estrada M, Salat J, Cruzado A (2005) Spatio-temporal variability of size fractioned phytoplankton on the shelf adjacent to the Ebro river (NW Mediterranean). Cont Shelf Res 25:1081-1095

Besag J (1974) Spatial interaction and the statistical analysis of lattice systems. J R Stat Soc, B 36:192-236

Blomdahl A, Breife B, Holmström N (2002) Flight identification of European seabirds. Christopher Helm, London

Bricaud A, Bosc E, Antoine D (2002) Algal biomass and sea surface temperature in the Mediterranean Basin. Intercomparison of data from various satellite sensors, and implications for primary production estimates. Remote Sens Environ 81:163-178

Burger J, Gochfeld M (1996) Family Laridae (gulls). In: del Hoyo J, Elliot A, Sargatal J (eds) Hoatzin to auks. Handbook of the birds of the world. Lynx Edicions, Barcelona, p 572-623

Cama A, Abellana R, Christel I, Ferrer X, Vieites DR (2012) Living on predictability: modelling the density distribution of efficient foraging seabirds. Ecography. doi: 10.1111/j.1600-0587.2011.06756.x

Chapman EW, Ribic CA, Fraser WR (2004) The distribution of seabirds and pinnipeds in Marguerite Bay and their relationship to physical features during austral winter 2001. Deep-Sea Res II 51:2261-2278

Christensen TK, Clausager I, Petersen IK (2001) Base-line investigations of birds in relation to an offshore wind farm at Horns Rev: results and conclusions 2000/2001. NERI 
(National Environmental Research Institute) report. Accessed 1 July 2010. www.hornsrev.dk/Miljoeforhold/ miljoerapporter/Baseline_investigations_of_birds.pdf

Cramp S, Simmons KEL (2004) Birds of the western Palearctic on interactive DVD-ROM. Birdguides, Oxford University Press, Oxford

Croxall JP, Prince PA, Reid K (1999) Diet, provisioning and productivity responses of marine predators to differences in availability of Antarctic krill. Mar Ecol Prog Ser 177: 115-131

Dementev GP, Gladkov NA (1969) Birds of the Soviet Union. Vol. 3. Israel program for scientific translations, Jerusalem

Fasola M, Bogliani G, Saino N, Canova L (1989) Foraging, feeding and time-activity niches of eight species of breeding seabirds in the coastal wetlands of the Adriatic Sea. Ital J Zool 56:61-72

Fauchald P (2009) Spatial interaction between seabirds and prey: review and synthesis. Mar Ecol Prog Ser 391: 139-151

Fischer JB, Larned WW (2004) Summer distribution of marine birds in the western Beaufort Sea. Arctic 57:143-159

> Fox AD, Desholm M, Kahlert J, Christensen TK, Petersen IK (2006) Information needs to support environmental impact assessment of the effects of European marine offshore wind farms on birds. Ibis 148:129-144

Furness RW, Camphuysen CJ (1997) Seabirds as monitors of the marine environment. ICES J Mar Sci 54:726-737

García A, Palomera I (1996) Anchovy early life history and its relation to its surrounding environment in the western Mediterranean basin. Sci Mar 60:155-166

Gray BR (2005) Selecting a distributional assumption for modeling relative densities of benthic macroinvertebrates. Ecol Modell 185:1-12

Gremillet D, Lewis S, Drapeau L, van Der Lingen CD and 6 others (2008) Spatial match-mismatch in the Benguela upwelling zone: should we expect chlorophyll and seasurface temperature to predict marine predator distributions? J Appl Ecol 45:610-621

Hernández-Matías A, González-Solís J (2004) Xatrac comú Sterna hirundo. In: Estrada J, Pedrocchi V, Brotons L, Herrando S (eds) Atles dels ocells nidificants de Catalunya 1999-2002. Institut Català d'Ornitologia (ICO)/ Lynx Edicions, Barcelona, p 250-251

Hüppop O, Wurm S (2000) Effects of winter fishery activities on resting numbers, food and body condition of large gulls Larus argentatus and L. marinus in the south-eastern North Sea. Mar Ecol Prog Ser 194:241-247

> Hyrenbach KD, Veit RR, Weimerskirch H, Metzl N, Hunt GL Jr (2007) Community structure across a large-scale ocean productivity gradient: marine bird assemblages of the southern Indian Ocean. Deep-Sea Res I 54: 1129-1145

Kitaysky AS, Hunt GL Jr, Flint EN, Rubega MA, Decker MB (2000) Resource allocation in breeding seabirds: responses to fluctuations in their food supply. Mar Ecol Prog Ser 206:283-296

Lambert D (1992) Zero-inflated Poisson regression, with an application to defects in manufacturing. Technometrics 34:1-14

> Lawless JF (1987) Negative binomial and mixed poisson regression. Can J Stat 15:209-225

Louzao M, Hyrenbach KD, Arcos JM, Abelló P, Gil de Sola L, Oro D (2006) Oceanographic habitat of an endangered Mediterranean procellariiform: implications for marine protected areas. Ecol Appl 16:1683-1695
Martínez-Vilalta A, Máñez M, Oro D, García L (2004) Gaviota picofina (Larus genei). In: Madroño A, González C, Atienza JC (eds) Libro rojo de las aves de España. Dirección General para la Biodiversidad-SEO/Birdlife, Madrid, p 240-242

McCulloch CE, Searle SR (2001) Generalized, linear and mixed models. John Wiley \& Sons, New York, NY

Meinertzhagen R (1954) The birds of Arabia. Oliver \& Boyd, Edinburgh

Mestres M, Sierra JP, Sánchez-Arcilla A, González del Río J, Wolf T, Rodríguez A, Ouillon S (2003) Modeling of the Ebro River plume. Validation with field observations. Sci Mar 67:379-391

Montevecchi WA, Benvenuti S, Garthe S, Davoren GK, Fifield D (2009) Flexible foraging tactics by a large opportunistic seabird preying on forage- and large pelagic fishes. Mar Ecol Prog Ser 385:295-306

> Morel A, Berthon JF (1989) Surface pigments, algal biomass profiles, and potential production of the euphotic layer: relationship reinvestigated in view of remote sensing applications. Limnol Oceanogr 34:1545-1562

Mösso C, Mestres M, Sánchez-Arcilla A, Sierra JP, González del Río J, Rodilla M, López F (2003) River plume behaviour in the Spanish Mediterranean coast. Hydro-morphodynamic controls. In: Sánchez-Arcilla A, Bateman A (eds) Proc 3rd IAHR Symp on River, Coastal and Estuarine Morphodynamics, RCEM. IAHR, Barcelona, p 935-945

Navarro J, González-Solís J (2007) Experimental increase of flying costs in a pelagic seabird: effects on foraging strategies, nutritional state and chick condition. Oecologia 151:150-160

Noer H, Christensen TK, Clausager I, Petersen IK (2000) Effects on birds of an offshore wind park at Horns Rev: Environmental impact assessment. NERI (National Environmental Research Institute) report. Accessed 30 April 2010. www.hornsrev.dk/miljoeforhold/miljoerapporter/Baggrundsrapport_18.pdf

Olivar MP, Salat J, Palomera I (2001) Comparative study of spatial distribution patterns of the early stages of anchovy and pilchard in the NW Mediterranean sea. Mar Ecol Prog Ser 217:111-120

Olsen KM, Larsson H (2003) Gulls of Europe, Asia and North America. 2nd edn. Christopher Helm, London

Orians GH, Pearson NE (1979) On the theory of central place foraging. In: Horn DJ, Mitchell RD, Stairs GR (eds) Analysis of ecological systems. Ohio State University Press, Columbus, p 154-77

Oro D (1996) Effects of trawler discard availability on egg laying and breeding success in the lesser black-backed gull Larus fuscus in the western Mediterranean. Mar Ecol Prog Ser 132:43-46

> Oro D (2002) Breeding biology and populations dynamics of slender-billed gulls Larus genei at the Ebro Delta (western Mediterranean). Waterbirds 25:67-77

> Oro D, Ruiz X (1997) Exploitation of trawler discards by breeding seabirds in the northwestern Mediterranean: differences between the Ebro Delta and the Balearic Islands areas. ICES J Mar Sci 54:695-707

Oro D, Tavecchia G (2008) Gaviota picofina. In: Bertolero A, Martínez-Abraín A, Molina B, et al. (eds) Gaviotas cabecinegra, picofina, de Audouin, tridáctila y gavión Atlántico. SEO/Birdlife, Madrid, p 21-42

Oro D, Jover L, Ruiz X (1996) Influence of trawling activity on the breeding ecology of a threatened seabird, Au- 
douin's gull Larus audouinii. Mar Ecol Prog Ser 139: 19-29

Oro D, Martínez-Vilalta A, Bertolero A (2004) Gavina capblanca Larus genei. In: Estrada J, Pedrocchi V, Brotons L, Herrando S (eds) Atles dels ocells nidificants de Catalunya 1999-2002. Institut Català d'Ornitologia (ICO)/ Lynx Edicions, Barcelona, p 234-235

> Ortiz M, Arocha F (2004) Alternative error distribution models for standardization of catch rates of non-target species from a pelagic longline fishery: billfish species in the Venezuelan tuna longline fishery. Fish Res 70 : 275-297

Palomera I, Olivar MP, Salat J, Sabatés A, Coll M, García A, Morales-Nin B (2007) Small pelagic fish in the NW Mediterranean Sea: an ecological review. Prog Oceanogr 74:377-396

Pons X (2011) MiraMon. Programa de consulta visualització, consulta, edició i anàlisi d'informació geogràfica. V 7.0. Generalitat de Catalunya and Universtotat Autònoma de Barcelona, Bellaterra. www.creaf.uab.es/miramon/index _es.htm

Sabatés A, Olivar MP, Salat J, Palomera I, Alemany F (2007) Physical and biological processes controlling the distribution of fish larvae in the NW Mediterranean. Prog Oceanogr 74:355-376

Salat J, Garcia MA, Cruzado A, Palanques A and 7 others (2002) Seasonal changes of water mass structure and shelf slope exchanges at the Ebro Shelf (NW Mediterranean). Cont Shelf Res 22:327-348

Shealer D (2002) Foraging behaviour and food of seabirds. In: Schreiber EA, Burger J (eds) Biology of Marine Birds. CRC Press, Boca Raton, FL, p 137-178

Editorial responsibility: Matthias Seaman, Oldendorf/Luhe, Germany
Stenhouse IJ, Montevecchi WA (1999) Indirect effects of the availability of capelin and fishery discards: gull predation on breeding storm-petrels. Mar Ecol Prog Ser 184: 303-307

> Suryan RM, Irons DB, Benson J (2000) Prey switching and variable foraging strategies of black-legged kittiwakes and the effect on reproductive success. Condor 102: 374-384

Tasker ML, Camphuysen CJ, Cooper J, Garthe S, Montevecchi WA, Blaber SJM (2000) The impacts of fishing on marine birds. ICES J Mar Sci 57:531-547

- Villablanca R, Luna-Jorquera G, Marín VH, Garthe S, Simeone A (2007) How does a generalist seabird species use its marine habitat? The case of the kelp gull in a coastal upwelling area of the Humboldt Current. ICES J Mar Sci 64:1348-1355

> Vincenzi S, Caramori G, Rossi R, De Leo GA (2006) Estimating clam yield potential in the Sacca di Goro lagoon (Italy) by using a two-part conditional model. Aquaculture 261:1281-1291

- Votier SC, Bearhop S, Ratcliffe N, Furness RW (2004a) Reproductive consequences for great skuas specializing as seabird predators. Condor 106:275-287

Votier SC, Furness RW, Bearhop S, Crane JE and 11 others (2004b) Changes in fisheries discard rates and seabird communities. Nature 427:727-730

Wanless S, Harris MP, Redman P, Speakman JR (2005) Low energy values of fish as a probable cause of a major seabird breeding failure in the North Sea. Mar Ecol Prog Ser 189:117-123

Weimerskirch H (2007) Are seabirds foraging for unpredictable resources? Deep-Sea Res II 54:211-223

Submitted: July 5, 2010; Accepted: June 4, 2012

Proofs received from author(s): August 20, 2012 